\title{
ANALISA TINGKAT RESAPAN TANAH BERDASARKAN PENGUKURAN PERMEABILITAS TANAH (Studi Kasus Kecamatan Tampan Kota Pekanbaru)
}

\author{
Usman Malik ${ }^{1, *}$, Indra Gunawan ${ }^{2, *}$, Juandi, $\mathbf{M}^{1}$ \\ ${ }^{1}$ Dosen Jurusan Fisika \\ ${ }^{2}$ Mahasiswa Program Studi S1Fisika \\ Fakultas Matematika dan Ilmu Pengetahuan Alam, \\ Universitas Riau Kampus Bina Widya \\ J1. Prof. Muchtar Luthfi Pekanbaru, 28293, Indonesia \\ *E-mail: usman.malik@lecturer.unri.ac.id \\ indragoenawan22@gmail.com
}

\begin{abstract}
Research was conducted to analyze the soil absorption level based on measurements of soil permeability in District Tampan Pekanbaru City, by taking soil samples for 16 units in four villages namely Simpang Baru, Delima, Tuah Karya, and Sidomulyo Barat which consists of four research blocks. Data inputted into the surfer's software 11 to be processed so as to produce a contour map of soil absorption level. The results that highest soil absorption of the land in Tuah Karya Village of 108,090.50 $\mathrm{m}^{3} /$ year whereas lowest soil absorption of the land in Simpang Baru Village of 91,149.35 $\mathrm{m}^{3} /$ year. High soil absorption level caused by open spaces area was large and the amount of rainfall that absorbed into the soil and soil absorption coefficient was high. While the low soil absorption level caused by open spaces area was small and the least rainfall that absorbed into the soil and the soil absorption coefficient is low.
\end{abstract}

Keywords: soil absorption level, soil permeability, open spaces area, rainfall, soil absorption coefficient.

\begin{abstract}
ABSTRAK
Telah dilakukan penelitian untuk menganalisa tingkat resapan tanah berdasarkan pengukuran permeabilitas tanah di Kecamatan Tampan Kota Pekanbaru, dengan mengambil sampel tanah sebanyak 16 buah di empat kelurahan yakni Kelurahan Simpang Baru, Delima, Tuah Karya, dan Sidomulyo Barat yang terdiri dari empat blok lokasi penelitian. Data yang diperoleh diinput ke dalam software surfer 11 untuk diproses sehingga menghasilkan peta kontur tingkat resapan tanah. Hasil yang diperoleh bahwa resapan tanah tertinggi yaitu terdapat di Kelurahan Tuah Karya sebesar 108.090,50 $\mathrm{m}^{3} /$ tahun sedangkan resapan tanah terendah terdapat di Kelurahan Simpang Baru sebesar 91.149,35 $\mathrm{m}^{3} /$ tahun. Tingkat resapan tanah yang tinggi disebabkan oleh luas lahan terbuka yang besar dan banyaknya curah hujan yang diresap ke dalam tanah serta koefisien resapan tanahnya tinggi. Sedangkan tingkat resapan tanah yang rendah disebabkan oleh luas lahan terbuka yang kecil dan sedikitnya curah hujan yang diresap ke dalam tanah serta koefisien resapan tanahnya rendah.
\end{abstract}

Kata kunci: Tingkat resapan tanah, permeabilitas tanah, luas lahan terbuka, curah hujan, koefisien resapan tanah.

\section{PENDAHULUAN}

Air tanah merupakan sumber daya yang sangat penting dalam penyediaan air di Indonesia. Penggunaan air tanah sangat luas dan memenuhi sekitar $60 \%$ dari kebutuhan penduduk terhadap air baik untuk irigasi, industri, air minum, mandi, cuci, kakus, dan lain-lain. Ketersediaan air tanah di setiap daerah ditinjau dari distribusinya tidak selalu sama, ada daerah dengan potensi air yang sangat besar tetapi ada pula yang potensinya sangat kecil serta bergantung pada besar kecilnya curah hujan.

Air tanah adalah air yang bergerak di dalam tanah yang terdapat di dalam ruang antar butir-butir tanah yang meresap ke dalam tanah dan bergabung membentuk lapisan tanah yang disebut akuifer. Apabila pada awal terjadinya hujan tanah dalam keadaan kering, sejumlah air hujan akan diserap untuk membasahi butiran-butiran tanah dan laju 
peresapan tinggi, sedangkan jika hujan masih berkelanjutan maka kapasitas tanah untuk menyerap air semakin menurun.

Resapan air tanah merupakan faktor yang sangat penting pada proses terbentuknya air tanah yang berfungsi sebagai penyeimbang atau penentu terpeliharanya kelestarian air tanah. Pengambilan air tanah yang banyak dan melampaui jumlah rata-rata dapat menyebabkan penurunan permukaan air tanah secara kontinu dan pengurangan potensi air tanah di dalam akuifer dan hal ini akan memicu terjadinya dampak negatif seperti penurunan kualitas air tanah dan penurunan permukaan tanah.

Daerah Provinsi Riau khususnya di Kecamatan Tampan Kota Pekanbaru merupakan wilayah yang cukup luas yaitu $59,81 \mathrm{~km}^{2}$ atau $9,46 \%$ dari luas wilayah Kota Pekanbaru serta perkembangan penduduk dan perekonomiannya semakin meningkat [1]. Faktor tersebut yang menyebabkan perubahan fungsi tata guna lahan. Sebagian besar lahan terbuka maupun hutan telah menjadi sejumlah area pemukiman, fasilitas umum pertokoan, dan perindustrian. Dampak dari perubahan tata guna lahan tersebut adalah meningkatnya limpasan permukaan langsung dan menurunnya daerah resapan air tanah.

Memanfaatkan potensi air tanah yang tersedia, perlu adanya studi tentang tingkat resapan tanah guna mengetahui dan menentukan besarnya potensi resapan air tanah.Potensi air tanah pada dasarnya merupakan jumlah air yang ada perkapita dalam kurun waktu tahunan [2]. Penentuan potensi air tanah selalu mengacu ketersediaan air tanah dan kualitas air tanah [3].

Perhitungan resapan air tanah perlu mempertimbangkan sifat fisis tanah/batuan dan lokasi yang ada. Harga resapan tanah bergantung kepada curah hujan, luas lahan terbuka, dan koefisien resapan tanah atau batuan di suatu daerah [4].

Pemanfaatan parameter fisis permeabilitas tanah untuk mengukur cepat lambatnya air melewati pori-pori tanah dapat digunakan untuk menentukan harga resapan air tanah, yang mana permeabilitas adalah sifat bahwa zat cair dapat mengalir melalui bahan berpori. Permeabilitas adalah cepat lambatnya air merembes ke dalam tanah baik melalui pori makro maupun pori mikro baik ke arah horizontal maupun vertikal. Sifat tanah yang memungkinkan air melewatinya pada berbagai laju alir tertentu disebut permeabilitas tanah. Sifat ini berasal dari sifat alami granular tanah, meskipun dapat dipengaruhi oleh faktor lain (seperti air terikat di tanah liat). Jadi, tanah yang berbeda akan memiliki permeabilitas tanah yang berbeda pula [5].

Permeabilitas tanah dalam keadaan jenuh dapat ditentukan mengikuti cara yang didasarkan pada Hukum Darcy.

$$
\mathrm{k}=\frac{\mathrm{V} \times \mathrm{L}}{\mathrm{A} \times \mathrm{h} \times \mathrm{I}}
$$

dimana $\mathrm{k}$ adalah permeabilitas tanah $(\mathrm{m} / \mathrm{s}), \mathrm{V}$ adalah volume tampung air $\left(\mathrm{m}^{3}\right)$, $\mathrm{L}$ adalah panjang sampel tanah (m), A adalah luas permukaan sampel tanah $\left(\mathrm{m}^{2}\right), \mathrm{h}$ adalah tinggi air dari permukaan sampel tanah (m), dan $\mathrm{t}$ adalah waktu penampungan (detik).

Tabel 1. Hubungan permeabilitas dengan nilai koefisien resapan tanah [6].

\begin{tabular}{|c|c|c|c|c|}
\hline No & Permesbilitas & Kcetisien resapan & Deshryai & Nilai \\
\hline 1 & Cepat (P30) & 0,3 & Singat tingei & 5 \\
\hline 2 & Agik cepar $(15-30)$ & 0,25 & Tingsi & 4 \\
\hline 3 & Sedang - sepat $(7-15)$ & 0,15 & Sedang & 3 \\
\hline 4 & Agak lanbut $(2-7)$ & 0,1 & Rendah. & 2 \\
\hline 5 & Launhat i 52$]$ & 0 & Sangat rencala & 1 \\
\hline
\end{tabular}

Tabel 1 dapat digunakan untuk menentukan hubungan permeabilitas tanah dengan koefisien resapan tanah berdasarkan deskripsi cepat atau lambatnya air merembes ke dalam pori-pori tanah.

Tabel 2. Klasifikasi permeabilitas tanah menurut Uhland dan O’Neil [7].

\begin{tabular}{|c|l|c|}
\hline No & \multicolumn{1}{|c|}{ Kelas } & Perneabilitas (ctujam) \\
\hline 1 & Sangat lambat & $<0,125$ \\
2 & Lambat & $0,125-0,50$ \\
3 & Agat lambat & $0,50-2,00$ \\
4 & Sedang & $2,00-6,25$ \\
5 & Agsk cepat & $6,25-12,50$ \\
6 & Cepat & $12,50-25,00$ \\
7 & Sangat cepat & $>25,00$ \\
\hline
\end{tabular}


Klasifikasi nilai permeabilitas dapat dilihat pada Tabel 2. Tabel 2 ini menunjukkan seberapa cepat air dapat melewati pori-pori tanah.

\section{METODOLOGI PENELITIAN}

Pengambilan sampel tanahdilakukan di Kecamatan Tampan Kota Pekanbaru sedangkan pengolahan data sampel tanah dilakukan di Laboratarium Fisika Bumi FMIPA UR.Metode yang dilakukan untuk menguji sampel tanah yaitu dengan mengalirkan air ke alat pengukur permeabilitas tanah.

Data yang diperoleh dari penelitian untuk menentukan tingkat resapan tanah berupa data literatur, lapangan, dan laboratorium. Prosedur penelitian ini ditunjukkan oleh bagan penelitian pada Gambar 1.

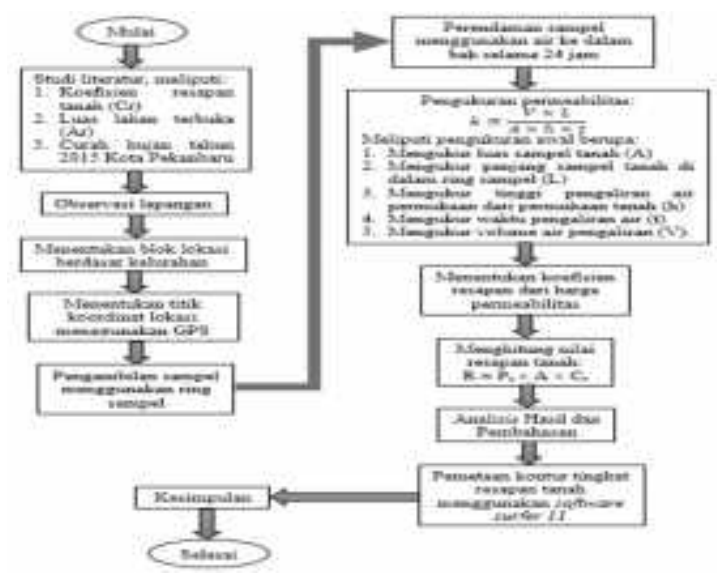

Gambar 1. Bagan Penelitian.

\section{HASIL DAN PEMBAHASAN}

Hasil penelitian yang diperoleh menunjukan tingkat resapan tanah di empat Kelurahan Kecamatan Tampan Kota Pekanbaru yaitu Kelurahan Simpang Baru, Delima, Tuah Karya, dan Sidomulyo Barat. Tingkat resapan tanah yang tinggi yaitu sebesar $155.000 \mathrm{~m}^{3} /$ tahun, sedangkan tingkat resapan tanah yang rendah yaitu sebesar $35.000 \mathrm{~m}^{3} /$ tahun.

Kelurahan Simpang Baru memiliki tingkat resapan tanah terendah dibandingkan Kelurahan Delima dan Sidomulyo Barat.
Meskipun luas lahan terbuka yang tersedia lebih besar yaitu 2,67 $\mathrm{km}^{2}$ dibandingkan Kelurahan Delima yaitu $2,42 \mathrm{~km}^{2}$ akan tetapi koefisien resapan tanah di Kelurahan Simpang Baru lebih rendah. Sementara itu di Kelurahan Sidomulyo Barat lahan terbuka yang tersedia lebih besar yaitu 2,85 $\mathrm{km}^{2}$ dibandingkan Kelurahan Delima dan Simpang Baru, akan tetapi harga koefisien resapan tanahyang dimilikinya lebih rendah dibandingkan dengan ketiga Kelurahan lainnya. Hal inilah yang menyebabkan lambatnnya air diresap oleh tanah di daerah Kelurahan Sidomulyo Barat.

Gambar 3 menunjukkan grafik perbandingan tingkat resapan tanah di setiap Kelurahan di Kecamatan Tampan Kota Pekanbaru dengan perbedaan warna di setiap Kelurahan.

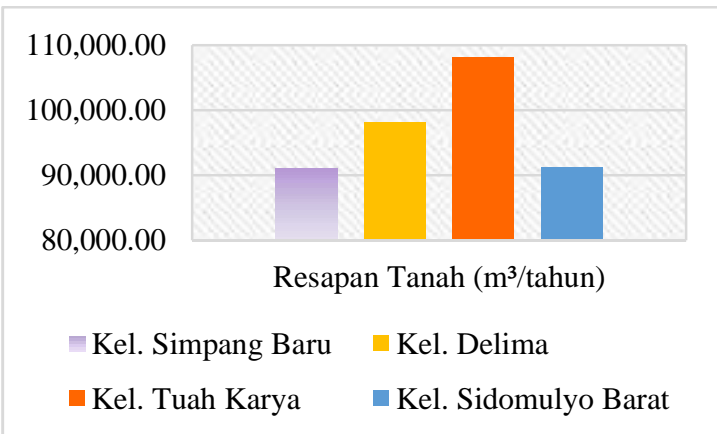

Gambar 2. Grafik perbandingan nilai resapan tanah di Kecamatan Tampan Kota Pekanbaru.

Gambar 2 menjelaskan bahwa pada garis vertikal berwarna biru di dalam kontur menginterpretasikan penampang lintang Utara ke Selatan sedangkan garis horizontal berwarna merah mewakili penampang bujur Barat ke Timur.

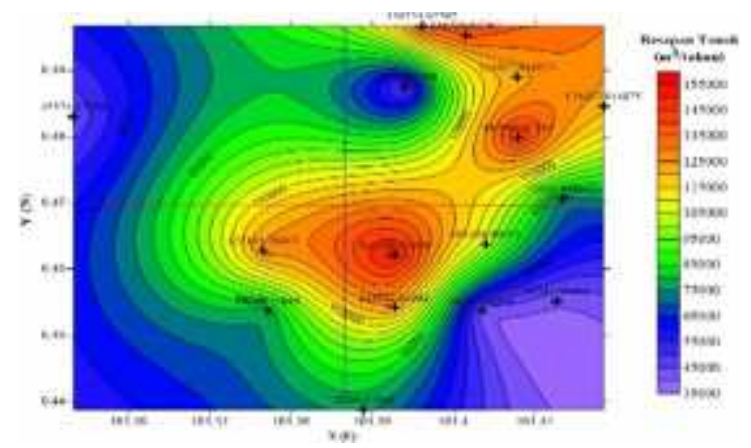

Gambar 3. Profil peta kontur tingkat resapan tanah di Kecamatan Tampan Kota Pekanbaru. 
Keluaran yang dihasilkan dari Gambar 3 yaitu berupa Profil 1 dan Profil 2 yang ditunjukkan pada Gambar 4 dan Gambar 5.

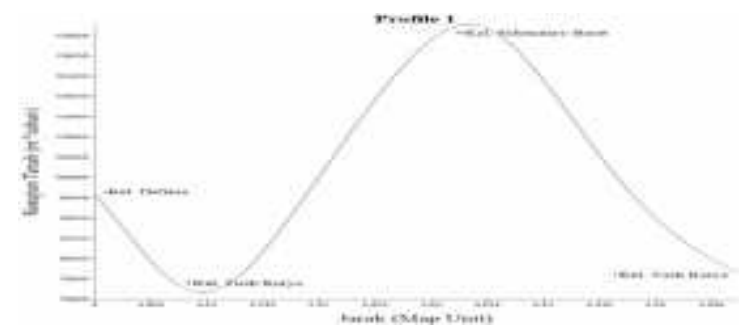

Gambar 4. Profil penampang lintang Utara ke Selatan.

Gambar 4 menunjukkan tingkat resapan tanah turun naik turun. Jarak 0 map unit sampai dengan 0,01 map unit tingkat resapan tanah menurun di daerah Kelurahan Tuah Karya. Kemudian pada jarak 0,01 map unit sampai dengan 0,035 map unit tingkat resapan tanah naik drastis mencapai titik resapan tanah $135.000 \mathrm{~m}^{3} /$ tahun di kawasan Kelurahan Sidomulyo Barat. Akhirnya pada jarak 0,035 map unit hingga 0,055 map unit tingkat resapan tanah turun secara eksponensial mencapai titik resapan tanah $75.000 \mathrm{~m}^{3} /$ tahun di kawasan Kelurahan Tuah Karya. Kenaikan tingkat resapan tanah yang drastis disebabkan oleh banyaknya curah hujan yang masuk ke dalam tanah pada daerah penampang tersebut dan koefisien resapannya yang tinggi. Sedangkan penurunan tingkat resapan tanah secara eksponensial disebabkan oleh sedikitnya curah hujan yang dapat masuk ke dalam tanah dan pada waktu yang lama di daerah penampang tersebut banyak limpasan air permukaan sehingga saat terjadinya hujan kembali tanah pada daerah ini lambat menyerap air sehingga koefisien resapannya rendah.

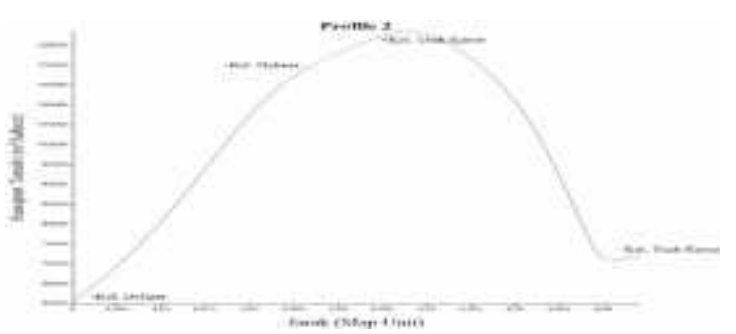

Gambar 5. Profil penampang bujur Barat ke Timur.
Gambar 5 menunjukkan tingkat resapan tanah yang cenderung naik kemudian turun. Jarak 0 map unit hingga 0,04 map unit tingkat resapan tanah mengalami kenaikan yang cukup tinggi mencapai puncak resapan tanah $125.000 \mathrm{~m}^{3} /$ tahun di kawasan Kelurahan Tuah Karya. Sedangkan pada jarak 0,04 map unit hingga 0,06 map unit tingkat resapan tanah mengalami penurunan mencapai titik resapan tanah $70.000 \mathrm{~m}^{3} /$ tahun kemudian tingkat resapan tanah tampak akan mengalami kenaikan di kawasan Kelurahan Tuah Karya. Kenaikan tingkat resapan tanah yang cukup tinggi disebabkan oleh banyaknya curah hujan yang masuk ke dalam tanah pada daerah penampang tersebut dan dalam waktu yang lama tanah di kawasan ini mengalami kekeringan sehingga saat terjadinya hujan tanah akan cepat menyerap air sehinggakoefisien resapan tanahnya tinggi. Sedangkan penurunan tingkat resapan tanah pada daerah yang dibatasi penampang bujur disebabkan oleh sedikitnya curah hujan yang dapat masuk ke dalam tanah pada daerah penampang dan koefisien resapan tanah yang rendah pada kawasan tersebut.

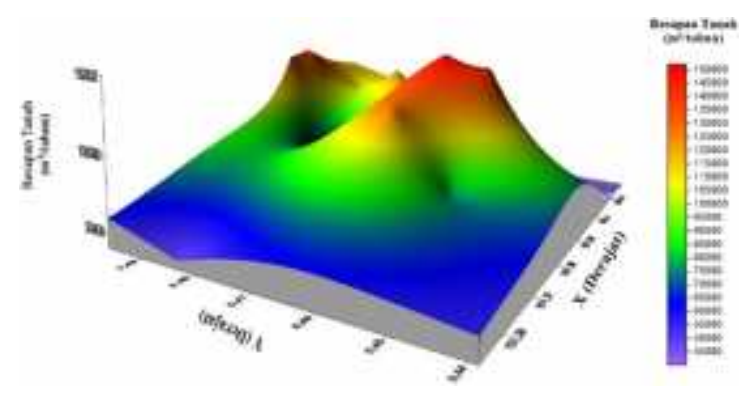

Gambar 6. Pemetaan tingkat resapan tanah di Kecamatan Tampan Kota Pekanbaru dalam tampilan 3D.

Gambar 6 merupakan peta kontur tingkat resapan tanah dalam tampilan 3D. Tingkat resapan tanah yang tinggi ditunjukkan oleh warna oranye pada puncak-puncak kontur dengan tingkat resapan tanah yaitu sebesar $150.000 \mathrm{~m}^{3} /$ tahun, sedangkan tingkat resapan tanah yang rendah ditunjukkan oleh skala warna ungu pada lembah-lembah kontur dengan tingkat resapan tanah yaitu sebesar $45.000 \mathrm{~m}^{3} /$ tahun. 


\section{KESIMPULAN}

Tingkat resapan tanah di Kecamatan Tampan Kota Pekanbaru memiliki kategori sedang dengan besar antara $0,00289 \mathrm{~m}^{3} /$ sekon hingga $0,00343 \mathrm{~m}^{3} /$ sekon. Tingkat resapan tanah ratarata tertinggi terletak di Kelurahan Tuah Karya dengan besar resapanyaitu 108.090,50 $\mathrm{m}^{3} /$ tahun. Sedangkan tingkat resapan tanah terendah terletak di Kelurahan Simpang Baru, dengan besar resapan yaitu 91.149,35 $\mathrm{m}^{3} /$ tahun. Penampang lintang Utara ke Selatan pada profil 1 menunjukkan tingkat resapan tanah turun naik lalu turun secara eksponensial.Kenaikan ini disebabkan oleh banyaknya curah hujan yang masuk ke dalam tanah pada daerah batasan penampang tersebut. Sedangkan penurunan secara eksponensial ini disebabkan oleh sedikitnya curah hujan yang dapat masuk ke dalam tanah dan pada waktu yang lama di daerah batasan penampang tersebut banyak limpasan air permukaan sehingga saat terjadi hujan kembali tanah semakinlambat menyerap air. Penampang bujur Barat ke Timur pada profil 2 menunjukkan tingkat resapan tanah yang cenderung naik kemudian turun. Kenaikan tingkat resapan tanah pada batasan penampang daerah ini disebabkan oleh banyaknya curah hujan yang masuk ke dalam tanah dan dalam waktu yang lama tanah di kawasan ini mengalami kekeringan sehingga saat terjadinya hujan tanah akan cepat meresapkan air. Sedangkan penurunan tingkat resapan tanah disebabkan oleh sedikitnya curah hujan yang masukke dalam tanah dan koefisien resapan tanahnya rendah.

\section{UCAPAN TERIMA KASIH}

Penulis mengucapkan terima kasih kepada Drs. Usman Malik, M.Si yang bersedia membimbing dan memberikan saran serta keikhlasan waktu dan ide kepada penulis demi kesempurnaan penulisan karya ilmiah ini.

\section{DAFTAR PUSTAKA}

1. Badan Pusat Statistik Provinsi Riau. (2014). Riau Dalam Angka. Pekanbaru: BPS.

2. Purnama, S., Suyono, \& Sulaswono, B. (2007). Sistem Akuifer dan Potensi Air Tanah Daerah Aliran Sungai (DAS) Opak. Forum Geografi, 21(2), 111-122.

3. Hidayat, R. S. (2008). Potensi Air Tanah di Cekungan Air Tanah Sambas Provinsi Kalimantam Barat. Jurnal Geologi Indonesia, 3(4), 205-216.

4. Juandi, M. \& Syech, R. (2018). The Ground Water Recharge Based on The Value of Soil Permeability. Applied Science and Technology, 2(1).

5. Juandi, M. \& Syahril, S. (2017). Empirical relationship between soil permeability and resistivity, and its application for determining the groundwater gross recharge in Marpoyan Damai, Pekanbaru, Indonesia. JournalWater Practice and Technology, 12(3).

6. Pusat Penelitian Tanah dan Agroklimat. (1993). Peta Jenis Tanah DAS Citarum Hulu Skala 1:100.000. Bogor: Balai Penelitian dan Pengembangan Pertanian Departemen Pertanian.

7. LPT (Lembaga Penelitian Tanah). (1979). Penuntun Analisa Fisika Tanah. Bogor: Badan Penelitian dan Pengembangan Pertanian. 